\title{
MIR31 wt Allele
}

National Cancer Institute

\section{Source}

National Cancer Institute. MIR31 wt Allele. NCI Thesaurus. Code C113231.

Human MIR31 wild-type allele is located in the vicinity of 9p21.3 and is approximately 0.1 $\mathrm{kb}$ in length. This allele, which encodes MIR31 pre-miRNA, may be involved in both tumor suppression and the modulation of transcription. 